\title{
LANGGAM CERITA RAKYAT BANYUMAS DALAM HARMONI NILAI KEARIFAN LOKAL
}

\author{
M. Riyanton, S.S., M.Pd. \\ Universitas Jenderal Soedirman, Jalan Dr. Soeparno, Karangwangkal Purwokerto \\ Utara Banyumas Jateng \\ Email: muhammadriyanton@gmail.com
}

\begin{abstract}
Abstrack
This article aims to describe the function of folklore for the people of Banyumas Regency. This article is qualitative descriptive. In this article the information is thoroughly described and analyzed. Data Papers are collected through several sources ie, informants, places of physical objects, and documents. Data collection techniques used includes direct observation, recording, interviews and document analysis. The sampling technique used is purposive sampling. Data validation technique used is triangulation of data / source and triangulation method. Data validation technique used is review informant. Analytical technique used is interactive model analysis (interactive model of analysis). The folklore of Banyumas collected and analyzed in this paper is three, namely (1) folklore "Babad Ajibarang: Djaka Mruyung", (2) folklore "Babad Sokaraja: Raden Kuncung", and (3) folklore "Batu Raden ". The study of folklore which contains has functions, among others: (1) as projective system, (2) as a means of ratification of institutions and cultural institutions, (3) as educational tools Pedagogical device (4) as a means of inspection and supervision so that the norms of society will always be adhered to its collective members. These four functions are found in this study.
\end{abstract}

Keywords: Folklore, Functions, and Values.

\section{PENDAHULUAN}

Indonesia merupakan salah satu negara di dunia yang mempunyai kekayaan nasional berupa keanekaragaman budaya. Sebagai kekayaan nasional, kebudayaan haruslah lebih dikembangkan dan dilestarikan. Masyarakat melihat kebudayaan sebagai manifestasi kehidupan manusia yang berbudi luhur dan bersifat ruhani, seperti agama, kesenian, filsafat, ilmu pengetahuan, dan tata negara, Anggapan seperti itu mulai berubah seiring dengan perubahan zaman. Dewasa ini, kebudayaan sering diartikan sebagai manifestasi kehidupan setiap orang dan setiap kelompok orang. Jadi, manusia tidak begitu saja di tengah-tengah alam, melainkan selalu mengubah alam itu. Dengan begitu, kebudayaan itu dapat dilihat dari model berusaha, seperti menggarap ladang, berdagang, ataupun melakukan sebuah penelitian.

Wujud budaya tidak bisa lepas dari sistem nilai yang dikuasai manusia. Manusia sebagai pelaku budaya mempunyai konsep yang hidup dalam alam pikirannya mengenai hal yang harus mereka anggap bernilai dalam hidup. Konsep pemikiran seperti itu pada akhirnya menimbulkan suatu sistem nilai budaya yang berfungsi sebagai pedoman tertinggi bagi kelakuan manusia. Mewariskan nilai lama dalam masyarakat memerlukan sebuah perantara untuk menyampaikannya, baik secara lisan maupun tulisan yang akan mengisi kebudayaan pada sepanjang zaman. Memengaruhi pola pikir masyarakat dan menjadi gambaran wujud masyarakat yang akan datang, memberi arah gerak pembangunan yang ada menjadi tolok ukur aktivitas kehidupan sehari-hari. Sebagai bukti nyata yaitu sastra lisan atau cerita rakyat.

Cerita rakyat Banyumas

menggambarkan kehidupan dari manifestasi kebudayaan. Sastra mengandung nilai-nilai religius dan humaniora yang universal. Keasliannya menggambarkan kehidupan manusia berbudaya. Nilai-nilai yang terkandung di 
dalamnya banyak memberikan ketauladanan bagi masyarakat. Sastra sebagai seni kreatif merupakan ungkapan dari hasil kesadaran atas realitas yang membentuk karikatur dari kenyataan dan pengalaman hidup yang akan diturunkan pada generasi berikutnya secara terusmenerus. Salah satu sumber kebudayaan nasional adalah cerita rakyat. Cerita rakyat di Indonesia merupakan bagian dari kebudayaan bangsa Indonesia. Cerita rakyat di Indonesia mempunyai peranan besar dalam kehidupan sosial budaya Indonesia, yakni pengungkap alam pikiran dan sikap sebagai harmoni nilai kebudayaan masyarakat serta sebagai penunjang kearifan lokal bahasa dan sastra Indonesia dan daerah.

Cerita rakyat yang dimiliki oleh masyarakat di Kabupaten Banyumas mempunyai peran sebagai kekayaan budaya khususnya kekayaan sastra lisan. Cerita rakyat merupakan bagian dari cerita rakyat yang masih tetap hidup dan dipertahankan oleh masyarakat Banyumas di Kabupaten Banyumas. Masyarakat begitu yakin dengan isi cerita rakyat yang ada di Kabupaten Banyumas. Karena itu diperlukan penelitian yang lebih mendalam untuk dapat membuktikan kepercayaan masyarakat terhadap cerita rakyat dan dilandasi begitu banyak cerita rakyat yang ada di Kabupaten Banyumas. Cerita rakyat tersebut tentu memiliki bentuk, isi, struktur, dan nilai pendidikan yang bervariasi. Melalui pendeskripsian unsurunsur yang ada dalam cerita rakyat dapat digali dan ditemukan nilai-nilai yang relevan dengan kehidupan masyarakat, misalnya nilai sosial budaya, nilai sejarah, nilai pendidikan, dan nilainilai yang lainnya. Nilai-nilai pendidikan yang terdapat dalam cerita rakyat, tanggapan masyarakat terhadap cerita rakyat di Kabupaten Banyumas dapat membentuk harmoni kearifan lokal yang terbalut dalam cerita rakyat.

\section{METODE PENELITIAN}

Metode yang digunakan dalam penelitian ini adalah metode penelitian deskriptif kualitatif. (Moleong, 2002: 6) dan objek penelitian adalah unsur-unsur yang bersama-sama dengan sasaran penelitian membentuk kata dan konteks data (Sudaryanto, 1993: 30). Objek dalam penelitian ini adalah (1) cerita rakyat "Babad Ajibarang: Djaka Mruyung", (2) cerita rakyat "Babad Sokaraja: Raden Kuncung", dan(3) cerita rakyat "Batu Raden". Sumber data primer dalam penelitian ini adalah cerita rakyat di Kabupaten Banyumas yang diperoleh secara lisan yang diceritakan oleh informan yaitu penduduk asli dan tokoh masyarakat. Teknik Pengumpulan Data dalam penelitian ini antara lain, observasi, wawancara, dan dokumentasi. Observasi dalam penelitian ini dilakukan dengan mengamati tempat atau lokasi Cerita Rakyat dan wawancara dilakukan kepada masyarakat pemiliknya, kepala desa, dan orang-orang yang memiliki keterkaitan dalam pemerolehan informasi yang berhubungan dengan penelitian cerita rakyat di Banyumas, serta dokumentasi dan dokumen penelitan ini adalah rekaman terhadap pencerita atau teks tertulis yang ada. Dalam penelitian ini proses analisis akan dilakukan dengan menggunakan model analisis interaktif menurut Miles dan Huberman (dalam Sutopo, 2002: 186)

\section{HASIL DAN PEMBAHASAN}

Cerita rakyat Kabupaten Banyumas merupakan cerita-cerita yang berlatar belakang adat/kebiasaan yang merupakan pengalaman hidup masyarakat pemiliknya. Cerita-cerita rakyat yang ada diserap dan dimanfaatkan sebagai pembentuk watak masyarakatnya. Pada masa dahulu cerita rakyat digunakan oleh para orang tua untuk pembentuk watak anak cucu dan keturunannya lewat tutur lisan yang digunakan di saat senggang atau pengisi waktu menjelang tidur dengan cara mendongeng. Pada saat mendongeng para 
orang tua menggunakan isi cerita untuk mendidik agar anak cucu dan keturunannya menjadi manusia yang hidup sesuai dengan norma-norma yang berlaku dalam masyarakat seperti tokoh dalam cerita dengan segala perilaku dan perannya.

Isi cerita rakyat yang disampaikan kepada anak cucu dan keturunannya diserap dan disampaikan untuk dapat memberikan petunjuk perilaku yang benar agar dapat diikuti, dan perilaku yang kurang benar agar dihindari atau dengan kata lain orang tua menekankan pada perilaku mana yang boleh dan perilaku mana yang tidak boleh. Cerita rakyat dapat pula digunakan sebagai alat penghibur dengan dibuat pementasan-pementasan sederhana yang ditonton masyarakat setempat untuk menumbuhkan rasa patriotik, cinta bangsa dan tanah air sekaligus pengobat rindu bagi kerabat yang ditinggalkan serta kebanggaan masyarakat pemiliknya.

Berdasarkan hasil observasi dan wawancara, kondisi seperti di atas jarang dijumpai bahkan di Kabupaten Banyumas kondisi seperti ini hampir langka dapat ditemui di daerah pedesaan, terlebih lagi di wilayah perkotaan. Tradisi atau adat kebiasaan bercerita yang lebih dikenal dengan istilah mendongeng yang pada zaman dahulu sering dilakukan para orang tua, di masa sekarang tidak lagi dijumpai. Banyak dari mereka berpandapat bahwa mendongeng sekarang sudah bukan zamannya.

Cerita yang paling populer di Kabupaten Banyumas antara lain yaitu (1) cerita rakyat "Babad Ajibarang: Djaka Mruyung", (2) cerita rakyat "Babad Sokaraja: Raden Kuncung", d a n (3) cerita rakyat "Batu Raden". Oleh karena itu, ketiga cerita tersebut yang diambil dalam penelitian ini untuk dikaji struktur, fungsi, dan nilai-nilai pendidikannya berdasarkan teori resepsi sastra.

Harmoni Nilai Kearifan Lokal Cerita Rakyat "Djaka Mruyung, Raden Kuncung, dan Baturaden"
1. Harmoni Nilai Moral

Sastra daerah yang berbentuk lisan maupun tulisan merupakan cagar budaya dan ilmu pengetahuan. Salah satu sastra daerah yang perlu dilestarikan adalah cerita rakyat. Setiap wilayah tentunya mempunyai cerita rakyat yang dituturkan secara lisan. Cerita rakyat yang pada mulanya dilisankan selain berfungsi untuk menghibur juga dapat memberikan pendidikan moral. Cerita rakyat Djaka Mruyung memiliki nilai moral jiwa ksatria, tanggung jawab, dan pantang menyerah, menghormati orang tua dan tidak boleh serakah.

Moral dalam cerita merupakan sarana yang berhubungan dengan ajaran moral tertentu yang bersifat praktis, yang dapat diambil dan ditafsirkan melalui cerita yang bersangkutan oleh pembaca. Cerita rakyat merupakan petunjuk tentang berbagai hal yang berhubungan dengan masalah kehidupan, seperti sikap, tingkah laku, dan sopan santun pergaulan.

2. Harmoni Nilai Adat

Cerita rakyat sebagai bagian dari ragam sastra dapat dikatakan menyimpan sejumlah informasi sistem budaya seperti filosofi, nilai, norma, perilaku masyarakat. Dalam hal ini terdapat nilai adat yang terkandung dalam cerita yang terkandung antara lain memunculkan nilai gotong royong. Hal tersebut dapat dilihat dari raden Djaka mruyung yang membabad hutan pakis haji yang dibantu oleh warga sekitar. Dari hal tersebut, sampai sekarang tradisi / adat gotong royong masih sangat kental di wilayah Banyumas filosofi polo pendem (menanam sesuai dengan kemampuannya), polo gumantung (manfaat), polo kasimpar (mendekatkan diri kepada Tuhan).. Selain itu, tradisi seperti seserahan sesaji ataupun peringatan ketika hari 
jadi Ajibarang dan Grebeg Suro di Baturaden sering dilakukan seperti pementasan wayang kulit.

3. Harmoni Nilai Agama

Pemahaman nilai religius yang tinggi akan mampu menanamkan sikap sabar, tidak sombong, dan angkuh kepada sesama. Pemahaman nilai religius juga akan menjadikan manusia saling mencintai dan saling menghormati. Lebih lanjut manusia akan mampu mewujudkan hidup yang harmonis antarmanusia dan hubungannya dengan Tuhan, alam, maupun makhluk yang lain. Dalam konteks kondisi keberagamaannya, Masyarakat Banyumas memiliki relasi antarumat beragama yang baik dan rukun. Pola interaksi sosial kerukunannya meliputi: pertama, interaksi teologis yang bersifat eksklusif (tertutup), yaitu interaksi antarumat beragama yang menyangkut relasi ketauhidan setiap agama dilakukan secara tertutup. Kedua, interaksi sosialnya bersifat inklusif (terbuka), yaitu hubungan antarumat beragama pada kehidupan sosial, seperti partisipasi sosial, keolahragaan, karang taruna, dan pemerintahan dilakukan secara bersama-sama dengan tidak ada pembeda-bedaan agama. Agama, dengan demikian, bagi masyarakat Sokaraja ditempatkan sebagai sistem kepercayaan (belief system) yang ritual ibadahnya hanya dilakukan oleh umatnya sendiri, sedangkan untuk urusan interaksi sosialnya berbaur dan bekerja sama dengan umat beragama lainnya.

4. Harmoni Nilai Sejarah

Karya sastra dipandang sebagai dokumen sosial. Naskah dan tradisi lisan warisan budaya leluhur bermanfaat untuk menggali perjalanan sejarah masyarakat lokal dan bangsa. Karya sastra, termasuk di dalamnya adalah cerita rakyat, sangat mungkin bermuatan kisah masa silam. Oleh karena itu kisah masa lalu dalam cerita rakyat merupakan fakta sejarah yang sesungguhnya. Namun, kandungan nilai sejarah dimungkinkan juga merupakan buah imajinasi pengarang. Nilai sejarah yang terkandung sangat banyak. Melalui cerita rakyat dapat diketahui asal-usul Ajibarang dan daerah sekitar Ajibarang secara berurutan. Selain itu, kita juga dapat mengenal siapa saja tokoh yang ada dalam cerita tersebut berdasarkan makam yang ada sebagai simbol.

Naskah dan tradisi lisan warisan budaya leluhur bermanfaat untuk menggali perjalanan sejarah masyarakat lokal dan bangsa. Melalui pengalaman, kejadian, atau peristiwa masa lampau dapat ditemukan hikmah atau nilai kehidupan masa kini dan masa-masa mendatang. Hal ini menjadi bukti bahwa cerita rakyat dapat memberikan nilai sejarah (historis) bagi generasi mendatang dan harmonisasi kearifan lokal yang ada di Banyumas

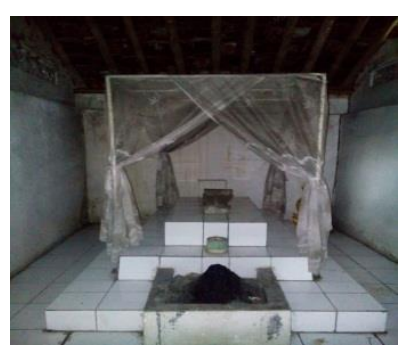

Gambar. 4.2. Makam Kenthol Ireng

Langgam cerita rakyat banyumas merupakan warisan yang disebarkan secara lisan dengan berbagai fungsi cerita bagi masyarakat pemiliknya dapat dipaparkan sebagai berikut.

1. Langgam Fungsi Cerita Rakyat "Djaka Mruyung" bagi Masyarakat Ajibarang

a) Fungsi Cerita Babad Ajibarang terhadap Masyarakat Sekitar

Cerita Djaka Mruyung mempunyai dampak kepercayaan bagi masyarakat Ajibarang khususnya yaitu sebagian masyarakat beranggapan bahwa para peziarah yang berdatangan ke Makam Djaka Mruyung biasanya mempunyai permintaan/tujuan tertentu yang konon 
apabila ingin cepat kesampaian harus melakukan laku tertentu. Ada juga sebagian masyarakat yang berpendapat lain, bahwa berziarah di makam tersebut adalah sebagai kegiatan ritual yang mengandung nilai keutamaan dengan menghayati dan mengenang jasa leluhur mereka. Selain itu, masyarakat mempercayai bahwa babad Ajibarang memang benar-benar ada. Hal tersebut dapat dilihat dari peninggalannya berupa terbentuknya nama Ajibarang dan nama-nama daerah lain disekitar Ajibarang. Selain itu, adanya makam dari Adipati Jaka Mruyung, Kenthol Ireng, Pandansari, dan Pandanayu. Makam tersebut dipercayai mempunyai nilai mistis dan biasanya sering dikunjungi oleh masyarakat sekitar untuk berziarah kubur seperti yang diungkapkan.

Pernyataan tersebut diperkuat dengan pendapat lain yang menyatakan bahwa menurut bapak Sudarmo, Warga Ajibarang mempercayai bahwa makam merupakan sesuatu yang sakral dan suci. Maka harus selalu dijaga keberadannya. Warga mempercayai bahwa makam tersebut merupakan bagian dari terbentuknya nama Ajibarang, sehingga dianggap sebagai sesuatu yang keramat .

Sebagian dari masyarakat di Indonesia menjadikan ziarah kubur sebagai suatu rutinan mingguan atau tahunan yang pasti di lakukan dengan istiqomah. Hal ini tidak dapat di bantah lagi karena, kenyataan yang ada memang membuktikan bahwa banyak dari kelompok masyarakat yang mentradisikan ziarah kubur, bahkan banyak dari mereka yang berbondong-bondong ziarah ke suatu makam yang dianggap sebagai makam keramat/suci tak terkecuali makam Adipati Jaka Mruyung, Kenthol Ireng, Pandansari dan Pandanayu.

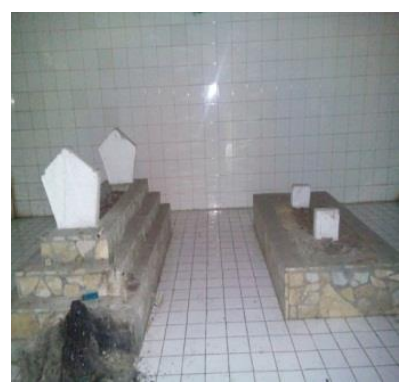

Gambar 1. Makam Djaka Mruyung
Dalam melakukan rutinitas ziarah kubur ternyata banyak dari masyarakat yang datang ke pemakaman serta membawa bunga-bunga untuk di taburkan di atas makam keluarga, tokoh masyarakat atau seseorang yang dianggap mulya, dengan berbagai tujuan di dalam menaburkan bunga, mereka seakan-akan lega dan plong jika sudah melihat pemakaman keluarga, tokoh masyarakat atau orang yang di anggap mulia sudah tertaburi dengan aneka macam bunga. Masyarakat menyadari terbentuknya nama Ajibarang tidak lepas dari cerita Djaka Muyung dan cerita tersebut merupakan sejarah bagi masyarakat Ajibarang.

\section{b) Fungsi Cerita Babad Ajibarang Terhadap Kebudayaan Masyarakat Ajibarang}

Cerita tersebut dapat memberikan pengaruh terhadap kebudayaan masyarakat berupa budaya gotong royong yang selalu dilakukan dalam berbagai hal, budaya sopan santun, serta budaya untuk selalu meghormati orang yang lebih tua.

Fungsi kepercayaan masyarakat terhadap resepsi cerita Djaka Mruyung juga mempengaruhi kebudayaan masyarakat, yaitu bagi kebanyakan orang tidaklah setiap hari menjadi waktu yang "pas" untuk berziarah ke makam-makam. Masyarakat yang masih memegang teguh adat "kejawen" yang tidak boleh di tinggalkan sebagai identitas budaya yang dimiliki. Adat yang selama ini berlaku yakni hari kamis lebih-lebih kamis "malam jum'at kliwon dan selasa kliwon" dipastikan menjadi "primadona" bagi pemegang teguh warisan budaya jawa, bahkan ini memberi pengaruh pada orang lain yang tidak beradatkan jawa sehingga ikut-ikutan ziarah makam pada hari kamis. Makam dianggap sebagai sesuatu yang suci, maka sebagian warga ada yang mempercayai ketika pada saat malam jum'at kliwon atau selasa kliwon dapat berkunjung dan berdoa disana, maka mereka akan mendapatkan apa yang mereka inginkan, tentunya selalu diikuti dengan usaha sehingga budaya berziarah 
kubur pada malam tersebut biasanya dilakukan oleh masyakat tertentu yang mempercayainya.

\section{c) Fungsi Cerita Djaka Mruyung terhadap Pendidikan Sekitar}

Cerita tersebut berfungsi untuk memberitahukan serta menginformasikan terhadap peserta didik, bahwa wilayah Ajibarang memang benar-benar ada ceritannya dan cerita tersebut akan menambah pengetahuan peserta didik mengenai cerita rakyat yang ada wilayah tersebut, meskipun kita tidak hidup pada zaman tersebut tetapi kita dapat mempelajarinya melalui buku. Cerita tersebut tentunya sebagai pengetahuan. Cerita babad Ajibarang juga sebagai salah satu materi yang dimuat dalam buku budaya banyumas. Budaya banyumas sebagai salah satu mata pelajaran yang diajarkan dengan tujuan untuk memberi pengetahuan kepada generasi muda mengenai sejarah daerah sekitar. Sebab, pada saat ini banyak sekali generasi muda yang melupakan sejarah masa lalu, meskipun itu mengenai sejarah didaerahnya sendiri.

\section{d) Fungsi Cerita Djaka Mruyung terhadap Keadaan Sosial Masyarakat}

Fungsi lain dari cerita rakyat adalah sebagai pengokoh nilai-nilai sosial budaya yang berlaku dalam masyarakat. Dalam cerita rakyat ajaran-ajaran etika dan moral bisa dipakai sebagai pedoman bagi masyarakat. Di samping itu di dalamnya juga terdapat larangan dan pantangan yang perlu dihindari. Cerita rakyat bagi warga masyarakat pendukungnya bisa menjadi tuntunan tingkah laku dalam pergaulan sosial. Melalui cerita tersebut dapat menumbuhkan jiwa sosial peserta didik, saling tolong menolong dan membantu sesama ketika sedang kesusahan.

\section{e) Fungsi Cerita Djaka Mruyung terhadap Perekonomian}

Petilasan Mbah/ Djaka Muyung banyak dikunjungi oleh masayarakat sekitar untuk berziarah. Kedatangan mereka selain ingin mendapatkan berkah juga dengan maksud agar permohonan mereka dapat terkabul melalui perantaraan doa sesepuh mereka. Para peziarah agar keinginannya terkabul sering mengadakan ritual dan slametan. Ritual ini sebagai bentuk ketulusan hati orang mempunyai hajat agar permintaanya segera dikabulkan Tuhan. Ritual yang sering diadakan di makam tersebut biasanya dilakukan perorangan. Mereka yang mempunyai hajat datang ke makam lalu dengan niatan yang baik dan tulus berpuasa. Puasa yang dilakukan biasanya puasa sehari penuh dan menu berbukanya dengan menu seadanya. Di samping berpuasa, mereka biasanya bermalam di areal makam. Oleh karena itu, pada saat hari besar banyak orang berziarah di makam tersebut sehingga banyak penjual bunga untuk menabur di makam Djaka Mruyung. Selain berjualan, masyarakat juga ada yang bertugas untuk menunjukkan makam Djaka Mruyung. Berdasarkan cerita babad Ajibarang, telah disebutkan bahwa Ajibarang nantinya akan menjadi suatu desa yang besar. Hal tersebut yang ada di dalam cerita, sudah dapat dibuktikan kebenarannya. Sebab pada saat ini , Ajibarang sudah menjadi pusat dan pasar yang dapat meningkatkan perekonomian masyarakat sekitar Ajibarang.

\section{Fungsi Cerita Rakyat "Raden Kuncung" bagi Masyarakat Sokaraja
a) Fungsi Cerita "Raden Kuncung" Terhadap Kepercayaan Masyarakat Sekitar}

Perdamaian yang ditempuh oleh kedua adipati itu diikuti dengan pernyataan Adipati Jebugkusuma yang menyatakan bahwa keturunan Sokaraja tidak boleh berbesanan dengan keturunan Purbalingga. Tabu nikah ini di-sebabkan oleh konflikkonflik yang terjadi sebelumnya. Nasib Raden Kaligenteng yang menjadi troublemaker dalam konflik-konflik Sokaraja-Purbalingga. 
Pengaruh fungsi babad Sokaraja terhadap kepercayaan masyarakat adalah masyarakat mempercayai sokaraja adalah gudangnya santri karena raden kuncung berguru ke muridnya sunan gunung jati dan pantangan bagi masyarakat purbalingga tidak boleh menikah dengan masyarakat sokaraja.

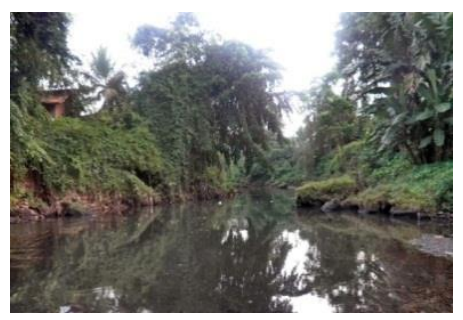

Gambar 2. Kali Pelus

Cerita rakyat Raden Kuncung memiliki pengaruh terhadap kepercayaan masyarakat yaitu dulu orang purbalingga benar-benar dilarang menikahi orang sokaraja namun sekarang sudah banyak orang purbalingga yang menikahi orang sokaraja, namun kepercayaan orang purbalingga dilarang mandi di sungai pelus masih menjadi pantangan karena takut mengalami perkara yang buruk. (Amin Supangat: Kepala Desa Karang Duren)

\section{b) Fungsi Cerita Rakyat Raden Kuncung terhadap Kebudayaan.}

Pentingnya mengkaji nilai-nilai yang terkandung dalam cerita rakyat, karena cerita rakyat itu memiliki fungsi kultural. Lahirnya suatu cerita rakyat bukan sematamata di dorong oleh keinginan penutur untuk menghibur masyarakatnya melainkan dengan penuh kesabaran ia ingin menyampaikan nilai-nilai luhur kepada generasi penerusnya. Cerita rakyat adalah golongan cerita yang hidup dan berkembang secara turun temurun dari satu generasi ke generasi berikutnya. Disebut cerita rakyat karena cerita ini hidup di kalangan rakyat dan hampir semua lapisan masyarakat mengenal cerita itu. Cerita rakyat milik masyarakat bukan milik seseorang. Pengaruh cerita rakyat Raden Kuncung dengan kebudayaan yaitu adanya kebudayaan orang tua yang menceritakan cerita rakyat Raden Kuncung kepada anaknya secara lisan.

\section{c) Fungsi Cerita Rakyat Raden Kuncung terhadap Pendidikan Masyarakat}

Cerita rakyat adalah suatu kebudayaan yang tumbuh dan berkembang di tengahtengah masyarakat itu yang diwarisi secara lisan sebagai milik bersama. Cerita rakyat tidak hanya berfungsi sebagai alat hiburan, pengisi waktu senggang serta penyalur perasaan bagi penuturnya serta pendengarnya, melainkan juga sebagai pencerminan sikap dan angan-angan kelompok, alat pendidikan, alat pengesahan pranata, dan lembaga kebudayaan serta pemeliharaan norma masyarakat. Fungsi cerita rakyat Raden Kuncung terhadap pendidikan yaitu adanya fungsi edukasi untuk mengajarkan pesan moral yang ada di dalam cerita tersebut yaitu seseorang tidak boleh serakah dan tidak boleh sembrono terhadap orang tua, harus menghormati orang yang lebih tua. Serta cerita tersebut termasuk dalam kumpulan cerita rakyat banyumas yang ada dalam mata pelajaran "Budaya Banyumas".

\section{d) Fungsi Cerita Rakyat Raden Kuncung terhadap Sosial Masyarakat}

Fungsi sosial masyarakat erita rakyat merupakan bagian dari karya sastra, maka dalam kebudayaan cerita itu termasuk dalam salah satu unsur kebudayaan. Cerita rakyat merupakan salah satu perwujudan atau pikiran kelompok masyarakat pendukungnya. Lahirnya cerita rakyat karena pengaruh timbal balik yang kompleks dari faktor-faktor sosial kultural dan cerita-cerita rakyat itu mengandung pikiran tentang nilai yang harus menjadi panutan masyarakat yang bersangkutan dalam menata tindakan sehari-hari. Pengaruh cerita Raden Kuncung terhadap sosial masyarakat yaitu saling mengingatkan jika ada orang purbalingga yang akan mandi di sungai pelus akan celaka. 


\section{e) Fungsi Cerita Rakyat Raden Kuncung terhadap Perekonomian Masyarakat Sokaraja}

Fungsi cerita rakyat raden kuncung belum memberikan pengaruh yang langsung atau nyata terhadap perekonomian masyarakat sekitar karena cerita-cerita seperti ini belum begitu popular.

Pengaruh fungsi babad sokaraja terhadap perekonomian masyarakat adalah pada saat itu hubungan perdagangan menjadi terputus karena perkelahian antar kadipaten, karena terjadi konflik maka bilateralnya tidak berlaku, dan Sokaraja bisa menjadi sekarang karena pada saat dulu sokaraja termasuk jalur yang strategis dalam hal transportasi dan perdagangan.

\section{Resepsi Fungsi Cerita Rakyat "Baturaden"}

\section{a) Fungsi Cerita Rakyat terhadap Kepercayaan Masyarakat}

Kepercayaan masyarakat terhadap cerita Baturaden terbagi menjadi 3 tipe golongan, yaitu manusia intelek, manusia agamis, dan manusia biasa. Berikut kutipan wawancaranya.

Rasa percaya setiap manusia berbedabeda, kepercayaan di golongkan menjadi 3 tipe, yaitu (1) manusia bangga dengan intelektualnya yang tinggi sehingga tidak percaya dengan mitos, mereka cenderung ingin membuktikan mitos tersebut dengan ilmu yang dimilikinya (2) masyarakat yang agamis, bisa percaya bisa juga tidak. (3) masyarakat biasa, yang pendidikannya kurang dan cenderung percaya dengan mitos yang ada di baturaden.

Resepsi masyarakat terhadap cerita baturaden mulai tumbuh seiring terbentuknya Lokawisata Baturaden yang menampakkan eksisitensi kepariwisataannya di masyarakat Secara fisik tidak Nampak. Akhir-akhir ini ada grebeg suran di sekitar daerah Baturraden yang berhubungan dengan asal-usul Baturraden. Berkaitan dengan tempat pancuran pitu dipercaya khasiat airnya bisa menyembuhkan gatal-gatal, khususnya gatal-gatal seperti Syekh Maulana Maghribi mandi secara teratur di tempat itu, dengan begitu dia sembuh dari penyakit gatalnya. Kalau zaman dahulu biasanya orang ke daerah pancuran tujuh untuk berobat dan meminta keselamatan.

b) Fungsi Cerita Rakyat Baturaden terhadap Kebudayaan Masyarakat

Wangsit Mbah Atas Angin diberikan kepada sesepuh Baturraden melalui mimpi, untuk melakukan selamatan. Hal ini berawal dari beberapa kejadian yang tidak biasa, yaitu banyak warga Baturraden yang tertimpa penyakit. Penyakit tersebut diantaranya hampir sama dengan yang diderita oleh Mbah Atas Angin pada waktu perjalanan menuju Gunung Slamet, yaitu Mbah Atas Angin menderita penyakit gatal-gatal yang susah disembuhkan. Berawal dari kejadian-kejadian yang tidak biasa kemudian ada sesepuh Baturraden yang diberi mimpi supaya tidak ada kejadian atau musibah yang maka harus mengadakan selamatan. Maka dari itu sampai sekarang selamatan dilestarikan untuk menghormati sesepuh yang mendirikan Baturraden yaitu Mbah Atas Angin."

Berdasarkan pernyataan di atas dapat diketahui bahwa upacara di Objek Wisata Baturraden berawal dari kejadiankejadian yang tidak biasa menimpa masyarakat Baturaden. Kejadian tersebut misalnya banyak masyarakat Baturaden yang tertimpa penyakit. Kemudian, ada seorang sesepuh Baturraden yang diberi wangsit melalui mimpi oleh Mbah Atas Angin, untuk melakukan selamatan setiap hari selasa atau Jumat Kliwon pada bulan Sura. Hal tersebut dilakukan supaya warga diberi keselamatan dan terhindar dari musibah.

c) Fungsi Cerita Rakyat Baturaden terhadap Pendidikan Masyarakat

Masyarakat awam banyak yang tidak mengetahui cerita baturraden, bahkan hanya masyarakat yang berpendidikan saja yang mengetahui karena di haruskan 
mengajakan cerita tersebut pada siswa sekolah dasar. Di sekolah paling disinggung dalam pelajaran tertentu, tentang kearifan lokal berhubungan dengan budaya-budaya banyumas.

\section{d) Fungsi Cerita Rakyat Baturaden terhadap Sosial Masyarakat \\ Cerita rakyat itu sebenarnya} diarahkan untuk memengaruhi kehidupan sosial masyarakat. Tapi zaman sekarang sepertinya masyarakat untuk terbawa dan percaya ke cerita itu sepertinya tidak begitu kental. Misalnya kalau dulu jalan ke pancuran tujuh itu tidak boleh untuk bilang capek, kesel, bahkan liat ular saja bilangnya oyod, namun hanya orang-orang tertentu yang masih terpengaruh cerita tersebut. Upacara yang dilakukan masyarakat seperti grebeg suran untuk mengangkat kearifan lokal daerah. Hal itu merupakan sesuatu yang positif karena pengunjung atau warga wilayah banyumas banyak yang berkunjung ke daerah tersebut.

\section{e) Fungsi cerita rakyat Baturaden terhadap masyarakat}

Perjalanan menuju ke objek wisata Batu Raden melewati jalur utama tidak terlalu menyulitkan karena rambu-rambu petunjuk arah sudah cukup jelas. Memasuki kawasan wisata, selain disuguhkan pemandangan pegunungan yang sejuk, tapi juga deretan hotel, losmen dan motel dari yang sederhana sampai mewah dengan harga bervariasi. Kawasan lokawisata Batu Raden terbilang cukup ramai, tidak dipengaruhi oleh musim libur. Setelah melewati gerbang masuk, pengunjung dihadapkan pada sebuah taman yang luas yang dikelilingi beberapa fasilitas penunjang seperti taman bermain anak, warung pedagang makanan khas seperti sate kelinci, jagung bakar, dan pecel desa, pos keamanan, dan ruang kesehatan. Baturraden menjadi tempat wisata Sangat berpengaruh, banyaknya di buka lapangan pekerjaan di sekitar daerah lokawisata baturraden. Kemajuan fisik sangat terlihat jelas dengan pembangunan insfraktuktur yang semakin baik.

\section{SIMPULAN}

Pengkajian cerita rakyat yang di dalamnya termuat 3 cerita rakyat memiliki kriteria langgam nilai dan fungsi kearifan lokal: (1) sebagai sistem proyeksi (projective system), (2) sebagai alat pengesahan pranata- pranata dan lembagalembaga kebudayaan, (3) sebagai alat pendidik anak (pedagogical device) (4) sebagai alat pemeriksa dan pengawas agar norma-norma masyarakat akan selalu dipatuhi anggota kolektifnya namun untuk poin yang ke 4 sudah mulai pudar karena perkembangan zaman. Keempat fungsi inilah yang ditemukan dalam kajian ini. Selain sebagai hiburan, juga merupakan sarana untuk mengetahui (1) asal-usul nenek moyang, (2) jasa atau teladan kehidupan para pendahulu, (3) hubungan kekerabatan (silsilah), (4) asal mula tempat, (5) adat-istiadat, dan (6) sejarah benda pusaka. Berawal dari penelitian ini diharapkan bisa menjadi refensi awal penelitian cerita rakyat yang ada di Banyumas lebih banyak lagi dan dari segi analisis sastra yang lain. Sementara dalam praktisnya penelitian ini diharapkan bisa menjadi dokumentasi budaya dan kemudian bisa ditindak lanjuti oleh pemerintah melalui dinas pariwisata untuk lebih memperhatikan aset-aset budaya daerah demi memajukan iklim pariwisata. Karena sejatinya salah satu aset terbesar yang dimiliki bangsa ini adalah kebudayaannya. 


\section{DAFTAR PUSTAKA}

Damono, Sapardi Joko. 1984. Sosiologi Sastra: Sebuah Pengantar Ringkas. Jakarta: Gramedia.

Endraswara, Suwardi. 2003. Metodologi Penelitian Sastra. Yogyakarta: Pustaka Widyatama.

Fananie, Zainuddin. 2001. Telaah Sastra. Surakarta: Muhammadiyah University press

Moleong, Lexy J. 2002. Metodologi Penelitian Kualitatif. Bandung: Remaja Karya.

Nurgiyantoro, Burhan. 2002. Teori Pengkajian fiksi. Yogyakarta: Gadjah Mada University Press.

Pradopo, Rachmat Djoko. 2003. Beberapa Teori Sastra, Metode Kritik, dan Penerapannya. Yogyakarta: Pustaka Pelajar.

Ratna, Nyoman Kutha. 2004. Teori, Metode, dan Teknik Penelitian Sastra. Yogyakarta: Pustaka Pelajar.

Russel, Bertrand. 1993. Pendidikan dan Tatanan Sosial (Edisi terjemahan oleh: A. Setiawan Abadi). Jakarta: Yayasan Obor Indonesia.

Sudaryanto. 1993. Metode dan Aneka Teknik Analisis Bahasa. Yogyakarta: Duta Wacana University Press.

Sutopo, H. B. 2002. Metode Penelitian Sastra: Epistemologi Model Teori dan Aplikasi. Yogyakarta: Pustaka Widyatama. 